\title{
Content validity of the nursing diagnosis powerlessness in women during natural childbirth*
}

\author{
Validação de conteúdo do diagnóstico de enfermagem sentimento de impotência em mulheres \\ durante o parto normal \\ Validación de contenido del diagnóstico de enfermería sentimiento de impotencia en mujeres \\ durante el parto normal
}

How to cite this article:

Apolônio FR, Pontes CM, Perrelli JGA, Sousa SMA, Mendes RCMG, Mangueira SO, Linhares FMP. Content validity of the nursing diagnosis powerlessness in women during natural childbirth. Rev Esc Enferm USP. 2021;55:e20210198. https://doi.org/10.1590/10.1590/1980-220X-REEUSP-2021-0198

\section{Fernanda Rocha Apolônio ${ }^{1}$ \\ Cleide Maria Pontes ${ }^{1}$ \\ Jaqueline Galdino Albuquerque \\ Perrelli ${ }^{1}$}

Santana de Maria Alves de Sousa ${ }^{2}$

Ryanne Carolynne Marques Gomes Mendes $^{1}$

Suzana de Oliveira Mangueira ${ }^{1}$

Francisca Márcia Pereira Linhares ${ }^{1}$

* Extracted from the dissertation: "Validação de conteúdo do diagnóstico de enfermagem sentimento de impotência em mulheres durante o parto normal", Universidade Federal de Pernambuco, Programa de Pós-Graduação em Enfermagem, 2020.

${ }^{1}$ Universidade Federal de Pernambuco, Centro de Ciências da Saúde, Programa de Pós-Graduação em Enfermagem, Recife, PE, Brazil.

${ }^{2}$ Universidade Federal do Maranhão, Centro de Ciências Biológicas e da Saúde, Programa de Pós-Graduação em Enfermagem, São Luís, MA, Brazil.

\section{ABSTRACT}

Objective: To validate the content of the nursing diagnosis powerlessness in women during natural childbirth. Method: A nursing diagnosis content validation, in which 29 experts analyzed the definition of powerlessness and assessed the relevance of related factors, populations at risk, associated conditions and defining characteristics. These elements were considered relevant when the Content Validity Index was greater than or equal to 0.9. Results: Experts considered the definition resulting from the concept analysis more appropriate for the diagnosis under study. Regarding the assessment of diagnostic elements, 10 related factors, two populations at risk, three associated conditions and 10 defining characteristics were considered relevant. Conclusion: The new definition for powerlessness and 25 elements have been validated by experts. These can support the operationalization of the Nursing Process for parturient women.

\section{DESCRIPTORS}

Nursing Diagnosis; Validation Studies; Natural Childbirth; Labor Presentation. 


\section{INTRODUCTION}

Natural childbirth is a defining moment in the lives of many women, as it allows the expression of emotions such as powerlessness. It is necessary that assistance to parturient women is based on scientific evidence, in order to favor the role of women and avoid this feeling. This assistance can be performed by nurses through the implementation of the nursing process $(\mathrm{NP})^{(1)}$.

Among the five stages of the NP, nursing diagnosis (ND) stands out, which can be identified through the operationalization of the Systematization of Nursing Care (SNC). From the identification of ND, it is possible to plan qualified assistance $^{(2-3)}$.

The NANDA Taxonomy (2018-2020) recommends that NDs be validated, in order to improve nursing language and improve healthcare for individuals ${ }^{(2)}$. This type of research contributes to building theoretical-conceptual knowledge and to the improvement, improvement and legitimacy of diagnoses ${ }^{(4-5)}$.

ND validation studies in Brazil are recent and generally employ three steps: concept analysis, expert content validation and clinical validation ${ }^{(5)}$. In content validation, the degree of agreement of experts on the relevance of the ND elements is measured ${ }^{(4)}$.

Moreover, content validation by experts provides an opportunity to update $\mathrm{DE}$ elements, in order to produce knowledge to guide clinical decision-making, especially to implement nursing interventions that are specific and effective in different scenarios of nurses' work such as the context of natural childbirth ${ }^{(2,4)}$.

Powerlessness was included in the NANDA-I Taxonomy in $1982^{(2)}$ and may be present in women during their natural childbirth, since their role and enforcement of their rights are sometimes affected ${ }^{(1,5-6)}$. This feeling corresponds to lack of power, physical/moral impossibility and lack of control over a situation, and is recognized as a human response subject to nursing intervention ${ }^{(2,7)}$.

Despite being included in the NANDA-I Taxonomy for a long time, this ND has not yet been validated in the context of natural childbirth, making this research necessary, which aims to contribute to updating the elements of ND through adjustments, with a view to effectively supporting the identification of diagnosis and nursing interventions aimed at promoting parturient women's health, as well as subsidizing the assistance of obstetric nursing. Thus, this study aimed to validate the content of porverlessness in women during natural childbirth.

\section{METHOD}

\section{Design of Study}

A content validation by powerlessness experts, carried out in 2019, in order to assess the diagnosis definition content and the relevance of antecedents (related factors, populations at risk and associated conditions) and consequences (defining characteristics), identified in a previous study on the analysis of the concept "powerlessness" in women during natural childbirth ${ }^{(8)}$.

\section{Population}

The study population consisted of nurses (with academic experience and/or practical experience in NDs and/or obstetrics) and psychologists. Expert recruitment took place through the Lattes Platform of the Brazilian National Council for Scientific and Technological Development ( $\mathrm{CNPq}$ - Conselho Nacional de Desenvolvimento Científico e Tecnológico), using the terms "validation of nursing diagnoses", "obstetrical nursing" and "women in labor". Searches were also carried out in the researcher's relational universe and the snowball technique was used, in which experts were asked to nominate others.

To classify the judges, level of expertise was calculated, represented by the formula $\mathrm{N}=(\mathrm{X}+\mathrm{Y}+\mathrm{Z}) / 3$, in which $\mathrm{X}$ corresponds to career length, $\mathrm{Y}$ corresponds to research group time and $\mathrm{Z}$ corresponds to scientific knowledge (degree, degree work and scientific production in the field of ND and/or obstetrics) $)^{(9)}$.

Experts were classified into: novice (value of $\mathrm{N}=1$ ), advanced beginner (value of $\mathrm{N}=2$ ), competent (value of $\mathrm{N}=3$ ), proficient (value of $\mathrm{N}=4$ ) and expert (value of $\mathrm{N}=5$ ). It is noteworthy that the calculation was made for leveling and was not used as an inclusion and exclusion criterion.

For the values of $\mathrm{X}, \mathrm{Y}$ and $\mathrm{Z}$, the following rules were assigned: career length of 0 years $(x=0)$; research group time of 0 years $(y=0)$; undergraduate degree, but no degree work in the study area or scientific production in the study area $(\mathrm{z}=0)^{(9)}$.

The practice of $1-7$ years presented the value $(x=1)$; research group time of $0-3$ years, $(y=1)$; being an expert, with a degree work in the study area or with scientific production in the study area, $(z=1)^{(9)}$.

When experts had a career length of 8-14 years, it was obtained $(x=2)$; research group time of 4-6 years, $(y=2)$; be a master, with a degree work in the study area or scientific production in the study area, $(z=2)$. When they had career length of 15-21 years, they obtained $(x=3)$; research group time of 7-9 years, $(\mathrm{y}=3)$; $\mathrm{PhD}$ with title work in the study area or with scientific production in the study area, $(z=3)^{(9)}$.

For career length of 22-28 years, it was obtained $(x=4)$ and research group time of $10-13,(y=4)$. In addition to this, for career length of 29 years or more, $(x=5)$ and research group time of 14 years or more, $(y=5)^{(9)}$.

\section{Selection Criteria}

Nurses with academic experience and/or practical experience with the subject of $\mathrm{DE}$ and/or obstetrics were included. Psychologists were also included due to the approach to the theme "powerlessness". Experts who did not respond to the invitation letter and those who responded to the instrument with inadequate completion were excluded. 


\section{Sample Definition}

The sample size definition was based on the estimate of the calculation of the average of the assessments for each element to be analyzed, using the following formula ${ }^{(4)}$ :

$$
n_{0}=\left(\frac{\mathrm{Z}_{1-\alpha / 2} \cdot S}{e}\right)^{2}
$$

The minimum sample totaled 23 experts, having as established parameters a confidence level $(Z 1-\alpha / 2)$ of $95 \%$, standard deviation (S) of 0.17 and sampling error (e) of 0.07 . It should be noted that this study had six more answers; therefore, the final sample consisted of 29 experts (23 nurses and six psychologists).

\section{Data Collection}

Experts were invited to participate in the study by means of an invitation letter, sent by email, with information about the objective and methodology of the research, and with guidance on the instrument and how it should be filled out.

Those who responded to the letter with acceptance to participate in the study were sent the Informed Consent Form (ICF) and the instrument. Experts were asked to respond to the instruments within a maximum period of 20 days. After the established date, those who did not respond were contacted again with a new deadline of 15 days to respond to the instrument. Those who did not respond within this period were excluded from the survey.

The first part of the instrument contained questions about experts' profile (profession, sex, region of work, current occupation and title). The second included the elements to be assessed from the ND under study, such as definition, related factors, risk populations, associated conditions, defining characteristics, as well as the conceptual and operational definitions of each item.

Thus, experts analyzed, regarding agreement, three definitions for the ND in question: Definition 1 - attributed by the NANDA-I Taxonomy (2018-2020) and Definitions 2 and 3 - constructed by the researchers through the attributes of powerlessness, identified in concept analysis ${ }^{(8)}$. Experts could bring suggestions, observations or considerations about the definitions presented.

Also, they analyzed the relevance of antecedents and consequences using a Likert-type scale, in which the score ranged from 1 to 5 (completely disagree (1); partially disagree (2); neither agree nor disagree (3); partially agree (4); totally agree (5)).

It is noteworthy that the list of antecedents and consequences contained the elements (related factors, defining characteristics, populations at risk and associated conditions) evidenced in the analysis of the concept "powerlessness". Of the 12 related factors evidenced, only three are in the NANDA-I Taxonomy (2018-2020) - dysfunctional institutional environment, anxiety and pain, and nine are new items $^{(8)}$.

For populations at risk and associated conditions, three and five new proposals were highlighted, respectively. As for the 10 defining characteristics, three are in the NANDA-I Taxonomy (2018-2020), with other nomenclatures - feeling of loss of control, dependence on decision-making and feeling of frustration, with seven new proposed items ${ }^{(8)}$.

\section{Data Analysis and Treatment}

Data were organized in program Microsoft Excel 2010 and analyzed in SPSS, version 21.0 and by software $R$, version 3.2.0. Descriptive statistics were presented by calculating frequencies (relative and absolute) for categorical variables, and for numerical variables, mean, median and standard deviation were presented.

Analysis of experts' judgment was performed using a Likert-type scale, elaborated in levels, in which, for each alternative, a different weight was assigned, namely: 1 equals $0 ; 2$ equals $0.25 ; 3$ equals $0.5 ; 4$ equals 0.75 ; and 5 equals 1 .

Normality was verified using the Shapiro-Wilk test. Due to non-normality, the weighted median of assessments was calculated. Expert analysis was weighted by their level of expertise. The Content Validity Index (CVI) was calculated using the predictive diversity model.

Confidence intervals (CI) of $95 \%$ and the Wilcoxon test were presented. This test considered a CVI $\geq 0.9$ as a reference value. It is noteworthy that, when the test's $\mathrm{p}$-value was $>0.05$, the items judged by experts were considered relevant. When $\mathrm{p}$-value was $<0.05$, they were considered irrelevant and excluded.

\section{ETHICAL AspeCts}

This study followed the Resolution 466/2012 guidelines of the Brazilian National Health Council (CNS - Conselho Nacional de Saúde) and was approved by the Institutional Review Board (IRB), under Opinion 3,373,636, in 2019. The ICF was sent by e-mail to participants for obtaining of consent by signing them in duplicate.

\section{RESULTS}

Experts were 23 obstetric nurses (69.0\%) and six psychologists (20.7\%). As for sex, 27 were women (93.1\%), and 25 lived in northeastern Brazil (86.2\%). With regard to title, 14 are experts (48.3\%), 11 hold a master's degree (37.9\%) and four are $\mathrm{PhD}(13.8 \%)$. Among the experts, 12 work in care (41.48\%), 12 work in care and teaching simultaneously (41.4\%) and five work only in teaching (17.2\%).

Regarding the level of expertise, most were classified as level 2 - advanced beginner (44.8\%). Subsequently, they were classified as level 3 experts - competent (17.2\%), level 4 - proficient (10.3\%) and level 5 - expert (6.9\%).

Factors related to unrealistic expectations and being a healthcare professional were excluded. Both are justified by the misunderstanding of the term and the association with the diagnosis. Additionally, some experts considered "being a healthcare professional" as a protective factor due to inherent knowledge. Thus, the researchers accepted the exclusion, since the item is under the support of little evidence (Table 1).

Extremes of age (adolescents and women over 35 years of age) was refuted by experts, as they disagreed that the age 
factor may influence making women more susceptible to developing powerlessness. These women have their pregnancies considered high risk and this factor was considered as a condition associated with porwerlessness and included in this classification (Table 2).

Multiple gestation was considered irrelevant, under the argument that the condition of having twins is not associated with powerlessness, but with the fact of becoming a high-risk pregnant woman. Thus, the suggestion to include bigh-risk pregnancy was strengthened. The use of analgesia was also not considered adequate, but some experts corroborated, emphasizing that analgesia has a protective factor for powerlessness.

Table 1 - Factors related to powerlessness in women during natural childbirth - Recife, PE, Brazil, 2020.

\begin{tabular}{|c|c|c|c|c|c|}
\hline \multirow{3}{*}{$\begin{array}{c}\text { Related factor* } \\
\text { Obstetric violence }\end{array}$} & \multirow{3}{*}{$\begin{array}{l}\text { CVI } \\
1.00\end{array}$} & \multirow{2}{*}{\multicolumn{2}{|c|}{$95 \% \mathrm{Cl}$}} & \multicolumn{2}{|c|}{ Wilcoxon test } \\
\hline & & & & \multirow{2}{*}{$\frac{V}{1891}$} & \multirow{2}{*}{$\begin{array}{c}\text { p-value } \\
1.000\end{array}$} \\
\hline & & 1.00 & 1.00 & & \\
\hline $\begin{array}{c}\text { Culture of } \\
\text { medicalization }\end{array}$ & 1.00 & 0.87 & 1.00 & 1225 & 0.545 \\
\hline $\begin{array}{l}\text { Insufficient knowledge } \\
\text { about role performance }\end{array}$ & 1.00 & 0.88 & 1.00 & 1378 & 0.860 \\
\hline Poor communication & 1.00 & 0.88 & 1.00 & 1378 & 0.860 \\
\hline Anxiety & 1.00 & 1.00 & 1.00 & 1711 & 0.999 \\
\hline $\begin{array}{l}\text { Negative past } \\
\text { experiences }\end{array}$ & 1.00 & 1.00 & 1.00 & 1770 & 1.000 \\
\hline Unrealistic expectations & 0.87 & 0.75 & 0.88 & 780 & 0.004 \\
\hline $\begin{array}{l}\text { Inadequate prenatal } \\
\text { care }\end{array}$ & 0.8 & 0.75 & 1.00 & 1081 & 0.217 \\
\hline $\begin{array}{l}\text { Dysfunctional } \\
\text { institutional } \\
\text { environment }\end{array}$ & 0.88 & 0.87 & 1.00 & 1081 & 0.217 \\
\hline Pain & 1.00 & 1.00 & 1.00 & 1653 & 0.998 \\
\hline $\begin{array}{l}\text { Being a healthcare } \\
\text { professional }\end{array}$ & 0.50 & 0.38 & 0.50 & 105 & 0.000 \\
\hline Fear & 1.00 & 1.00 & 1.00 & 2346 & 1.000 \\
\hline
\end{tabular}

* Shapiro-Wilk test: non-normality of data.

Source: Prepared by the authors.

Table 2 - Populations at risk and associated conditions for powerlessness in women during natural childbirth - Recife, PE, Brazil, 2020.

\begin{tabular}{cccccc}
\hline Population at risk* & \multirow{2}{*}{$\mathbf{C V I}$} & \multirow{2}{*}{$\mathbf{9 5} \mathbf{C l}$} & \multicolumn{2}{c}{ Wilcoxon test } \\
\cline { 5 - 7 } & & & & $\mathbf{V}$ & p-value \\
\hline Extremes of age & 0.75 & 0.63 & 0.87 & 465 & 0.000 \\
Primiparity & 0.88 & 0.88 & 1.00 & 1176 & 0.423 \\
Social vulnerability & 1.00 & 0.88 & 1.00 & 1275 & 0.665 \\
Associated conditions* & & & & & \\
Labor induction & 1.00 & 0.88 & 1.00 & 1378 & 0.860 \\
Dystocia & 1.00 & 1.00 & 1.00 & 1711 & 0.999 \\
Analgesia & 0.75 & 0.75 & 0.87 & 561 & 0.000 \\
Depression & 1.00 & 0.88 & 1.00 & 1485 & 0.962 \\
Multiple gestation & 0.75 & 0.75 & 0.87 & 351 & 0.000 \\
\hline
\end{tabular}

* Shapiro-Wilk test: non-normality of data.

Source: Prepared by the authors.
All defining characteristics for powerlessness were considered relevant, since p-value was greater than 0.05 (Table 3).

Through the identification of the attributes of the analysis of the concept "powerlessness", two definitions were constructed and suggested for the ND, which were analyzed for agreement by experts (Chart 1 ).

Regarding the definitions of the diagnosis, $58.6 \%$ of experts considered definition 3, constructed in the concept analysis, the most appropriate: "Emotional experience that results in feeling of disability, role impairment and lack of control over the situation experienced" (Table 4).

Table 3 - Defining characteristics of powerlessness in women during natural childbirth - Recife, PE, Brazil, 2020.

\begin{tabular}{|c|c|c|c|c|c|}
\hline \multirow{2}{*}{ Defining characteristics* } & \multirow{2}{*}{ CVI } & \multirow{2}{*}{\multicolumn{2}{|c|}{$95 \% \mathrm{Cl}$}} & \multicolumn{2}{|c|}{ Wilcoxon test } \\
\hline & & & & $\mathbf{V}$ & p-value \\
\hline $\begin{array}{l}\text { Dependence on } \\
\text { decision-making }\end{array}$ & 1.00 & 0.87 & 1.00 & 1225 & 0.545 \\
\hline $\begin{array}{l}\text { Disbelief in one's own } \\
\text { body }\end{array}$ & 1.00 & 1.00 & 1.00 & 1596 & 0.994 \\
\hline Sense of loss of control & 1.00 & 1.00 & 1.00 & 1953 & 1.000 \\
\hline Passivity to interventions & 1.00 & 0.88 & 1.00 & 1378 & 0.860 \\
\hline Feeling of insecurity & 1.00 & 1.00 & 1.00 & 1830 & 1.000 \\
\hline Feeling of frustration & 1.00 & 0.88 & 1.00 & 1485 & 0.962 \\
\hline Feeling of failure & 1.00 & 0.88 & 1.00 & 1275 & 0.665 \\
\hline Anguish & 1.00 & 1.00 & 1.00 & 1540 & 0.983 \\
\hline Hopelessness & 1.00 & 0.88 & 1.00 & 1485 & 0.962 \\
\hline Fear & 1.00 & 1.00 & 1.00 & 2346 & 1.000 \\
\hline
\end{tabular}

* Shapiro-Wilk test: non-normality of data.

Source: Prepared by the authors.

Chart 1 - Proposals for the definition of powerlessness - Recife, PE, Brazil, 2020.

\section{Definitions}

Definition 1: "The lived experience of lack of control over a situation, including a perception that one's actions do not significantly affect an outcome $^{\prime \prime(2)}$. (NANDA-I Taxonomy 2018-2020)

Definition 2: Emotional experience of lack of control over a situation, perception that the actions themselves do not affect a result, feeling of disability and role impairment. (Concept analysis)

Definition 3: Emotional experience that results in feeling of disability, role impairment and lack of control over the situation experienced. (Concept analysis)

Source: Apolônio FR, Validação de conteúdo do diagnóstico de enfermagem Sentimento de impotência em mulheres durante o parto normal [dissertation]. Recife: Universidade Federal de Pernambuco; 2020.

Table 4 - Definition of powerlessness in women during natural childbirth - Recife, PE, Brazil, 2020.

\begin{tabular}{ccc}
\hline Variables & N & $\%$ \\
\hline Definition established by NANDA-I & 3 & 10.4 \\
Definition 2 suggested for the ND & 9 & 31.0 \\
Definition 3 suggested for the ND & 17 & 58.6 \\
\hline
\end{tabular}

Source: Apolônio FR, Validação de conteúdo do diagnóstico de enfermagem Sentimento de impotência em mulheres durante o parto normal [dissertation]. Recife: Universidade Federal de Pernambuco, 2020. 
Experts agreed with definition 3, since they considered the one established by NANDA-I as incomplete. Thus, they judged this as the best definition for the ND, with no need for change.

\section{DISCUSSION}

Experts are mostly obstetric nurses, who are fundamental professionals in the midwifery scenario and have a clear understanding of theoretical and practical experience. Therefore, they can properly assess the context of women in the process of labor and birth ${ }^{(10)}$.

Experts considered the definition of powerlessness proposed by the NANDA-I Taxonomy $(2018-2020)^{(2)}$ as less comprehensive compared to the one suggested in this study, which included the term "role", which occurs through the knowledge of pregnant women about decisions, possibilities and rights. The development of this is not always automatic, so there is a need for strategic actions to obtain it ${ }^{(10)}$.

The NANDA-I definition states that powerlessness corresponds to a lived experience ${ }^{(2)}$, while the proposal that was best assessed by experts considers that this feeling refers to an emotional experience. Furthermore, the taxonomy implies that this experience is one of lack of control ${ }^{(2)}$. This research, on the other hand, proposes that the experience, as it involves the emotional context, results in this lack, in addition to causing the feeling of incapacity.

In order for women to feel capable and in control of situation experienced and not show powerlessness, educational actions are relevant factors, since they provide trust and harmony in the relationship between professional and pregnant woman, reducing subordination and favoring women's autonomy ${ }^{(11)}$.

Among the factors that were considered relevant by experts, obstetric violence stands out. This is conceptualized as the imposition of a significant degree of avoidable pain and suffering that is directly related to the power relationship that surrounds childbirth, encompassing a series of occurrences in the pregnancy-puerperal cycle that can be of a physical, psychological or sexual nature ${ }^{(12)}$.

Recently, in Brazil, there were discussions about obstetric violence. The Ministry of Health $(\mathrm{MoH})$ published a technical note in which it advocated abolishing the use of the term in public policies and norms, motivated by a request from medical entities that alleged stigmatization of the profession. After intervention by the Public Ministry and the population, the note was revoked and the $\mathrm{MoH}$ started to recommend that obstetric violence be strictly fought ${ }^{(13)}$.

All this movement added importance to the discussion and generated knowledge for women ${ }^{(14)}$. None of the experts delegitimized the term and all considered it a factor related to the emergence of powerlessness, in addition to reporting that obstetric violence is related to other components of the diagnosis.

Another item considered adequate was the culture of medicalization, which reminds us that childbirth is a phenomenon that undergoes changes according to the society in which it is inserted. The current obstetric scenario in Brazil reflects an institutionalization of practical knowledge associated with childbirth and invasive procedures, often unnecessary and potentially iatrogenic, which result in the loss of women's autonomy ${ }^{(14)}$.

In relation to insufficient knowledge, the same is seen in pregnant women who present inappropriate behavior and little participation in care. Experts considered this item relevant. In fact, no woman should arrive at the time of delivery without knowing well the phenomenon to be experienced and without having made choices in the preparation time ${ }^{(15)}$.

Experts also analyzed the inappropriate prenatal item as relevant and mentioned the importance of health education at this stage of life for women and their families. A research expert stated that little knowledge compromises women's autonomy and leading role, leading them to powerlessness. This information reinforces the fact that inadequate prenatal care can lead to feelings like this.

The term "prenatal" comes from preparation for birth and, therefore, it must offer all the support and guidance so that it is very well prepared. The needs, anxieties and particularities of each pregnant woman must be taken into account, based on the dialogic relationship, qualified listening, observation and educational strategies, praising them as leading actors of the process ${ }^{(16)}$.

The occurrence of powerlessness was also related to previously lived experiences with negative emotional outcomes, as these can have an impact on current experiences ${ }^{(17)}$. A woman who experiences a childbirth as a negative experience will take this mark to the next childbirth and this can lead to the exacerbation of several feelings, with prejudice to the moment of birth, if it is not redefined.

In contrast, studies within this theme show references from women who were driven to look for alternative models of care for themselves after bad obstetric experiences and contact with third-party stories that were not satisfactory to their expectations. In other researches, it also emerges that discontent with the care offered in hospitals has driven pregnant women to become better informed about the current experience ${ }^{(18-19)}$.

It can be understood that, despite negative previous experiences - personal and influenced - are related to powerlessness, it is also possible to use these experiences in favor of a different choice by women. For this end, it will be necessary to know and envision a new range of possibilities that, possibly, will be presented to them by the healthcare professional with whom they have greater contact. In this context, once again, educational strategies and holistic care stand out ${ }^{(10)}$.

In addition to these, poor communication and dysfunctional institutional environment were identified as related factors that could be minimized by healthcare professionals. One of the effective means of communication between pregnant woman and professional in this context was the use of a birth plan $(\mathrm{BP})^{(20)}$.

The use of $\mathrm{BP}$ is recommended by the World Health Organization (WHO). It is a written, legal document in which pregnant women express in advance their preferences and expectations regarding the care they would like to receive during labor and delivery ${ }^{(20)}$. 
BP considers pregnant woman's values, desires and personal needs, in order to avoid unwanted interventions. In addition to providing greater control over childbirth events, this planning favors communication between women and their caregivers, especially if they are unable to communicate effectively under certain circumstances such as a painful process such as labor ${ }^{(20)}$.

As for pain, it is known that its cycle occurs together with anxiety and fear - three factors related to powerlessness in this study. Fear is among the aspects that discourage natural childbirth and tension or anxiety, which is often intensified in the third trimester when the approaching birth is noticed $^{(21)}$. Recognizing these feelings in the context of childbirth is considered essential for effective support in coping with the process in a positive way, without powerlessness.

Experts analyzed and validated all defining characteristics suggested from the concept analysis. In their experiences, they consider that powerlessness brings as consequences dependence in decision-making and disbelief in one's own body. Furthermore, it generates a feeling of loss of control, makes women susceptible to interventions by the health team, and they show feelings such as insecurity, anguish, hopelessness, recurrently feeling frustrated and unsuccessful.

Such experienced situations bring to history negative marks of the experience, which will often be propagated to other generations, forming a new cycle of women who did not develop personal empowerment and do not star in this moment in their lives ${ }^{(22)}$.

Experts in this research consider that the belief that their body is capable of giving birth is liberating for women and is able to free them from many traumatic situations that are constantly related to the event of childbirth by the feeling of control and capability. Thus, feeling out of control raises the levels of the hormone cortisol and adrenaline while in labor, as they activate the neocortex. Such an occurrence is highly detrimental to the outcome of the birth ${ }^{(23)}$.

The feelings validated by experts as defining characteristics were: insecurity, which is related to feeling a lack of confidence and feeling at risk or unprotected; the feeling of frustration, which is the feeling of disappointment or disappointment for not being able to achieve the desired goal; the feeling of failure which is like a feeling of loss or failure to complete a goal; anguish, which is characterized as an unpleasant psychic feeling; and hopelessness, which happens when a woman feels the lack or loss of hope, giving way to discouragement or despair ${ }^{(2)}$.

Studying about feelings is not an easy task, due to the high degree of term abstraction. When placed in the natural childbirth scenario, subjectivity increases exponentially. The fact that feelings of different origins, including contradictory and imperceptible, permeates women during natural childbirth, is recognized in several studies, but breaking them down and specifying them from the extraction of the meaning of words is a complex task ${ }^{(2)}$.

In this study, it was necessary to use inference, as well as word dictionaries, to understand which feelings are from the same meaning source and to be able to use them in a more coherent way.

For experts, the characterization of these feelings as consequences of powerlessness is clear and legitimate and all this is directly related to role impairment. The absence of female empowerment is concerning. Denying the transcendence and abstraction of this phenomenon is to deliver women to incomplete care and add risks to their health and that of their babies ${ }^{(19,23)}$.

As a limitation of the research, the difficulty in gathering experienced experts in ND content analysis to compose the sample is understood. However, most participants had specialization and experience in obstetrics, which contributed to the quality of validation of the diagnosis under study.

The findings of this research contribute to implementing educational strategies and providing humanized care, in order to minimize powerlessness. It is expected to support the formulation of health education actions by nurses who work with women in the pregnancy-puerperal cycle through the identification of powerlessness.

\section{CONCLUSION}

A new definition for the diagnosis under study and 25 elements were validated by experts, suggesting that the NANDA-I Taxonomy has a gap. Five terms were not considered valid by this analysis: extremes of age (at risk population), multiple gestation and analgesia (associated conditions), unrealistic expectations and being a healthcare professional (related factors).

It is also suggested to carry out the third stage of the diagnostic validation studies, which consists of clinical validation, in order to test the findings of this study with women during the parturition experience and to support nurses' care practice for correct identification and implementation of effective interventions. Furthermore, since the definition of the ND and the labels of some of its elements were modified, as well as new proposals were validated, the results of this research will be submitted to the NANDA-I Taxonomy for possible updating.

\section{RESUMO}

Objetivo: Validar o conteúdo do diagnóstico de enfermagem sentimento de impotência em mulheres durante o parto normal. Método: Validação de conteúdo de diagnóstico de enfermagem, no qual 29 especialistas analisaram a definição do diagnóstico sentimento de impotência e avaliaram a relevância dos fatores relacionados, populações em risco, condições associadas e características definidoras. Esses elementos foram considerados relevantes quando o Índice de Validade de Conteúdo foi maior ou igual a 0,9. Resultados: Os especialistas consideraram a definição resultante da análise de conceito mais apropriada para o diagnóstico em estudo. Em relação à avaliação dos elementos do diagnóstico, 10 fatores relacionados, duas populações em risco, três condições associadas e 10 características definidoras foram consideradas relevantes. Conclusão: A nova definição para o diagnóstico de enfermagem sentimento de impotência e 25 elementos foram validados pelos especialistas. Estes podem subsidiar a operacionalização do Processo de Enfermagem às parturientes. 
DESCRITORES

Diagnóstico de Enfermagem; Estudos de Validação; Parto Normal; Trabalho de Parto.

\section{RESUMEN}

Objetivo: Validar el contenido del diagnóstico de enfermería sentimiento de impotencia en mujeres durante el parto normal. Método: Validación del contenido del diagnóstico de enfermería, en el que 29 expertos analizaron la definición del diagnóstico sentimiento de impotencia y evaluaron la relevancia de factores relacionados, poblaciones en riesgo, condiciones asociadas y características definitorias. Estos elementos se consideraron relevantes cuando el Índice de Validez de Contenido fue mayor o igual a 0,9. Resultados: Los expertos consideraron más adecuada la definición resultante del análisis de concepto para el diagnóstico en estudio. En cuanto a la evaluación de los elementos diagnósticos, se consideraron relevantes 10 factores relacionados, dos poblaciones en riesgo, tres condiciones asociadas y 10 características definitorias. Conclusión: La nueva definición del diagnóstico de enfermería sentimiento de impotencia y 25 elementos fueron validados por expertos. Estos pueden apoyar la operacionalización del proceso de enfermería para parturientas.

\section{DESCRIPTORES}

Diagnóstico de Enfermería; Estudios de Validación; Parto Normal; Presentación en Trabajo de Parto.

\section{REFERENCES}

1. Simpson KR, Lyndon A. Consequences of delayed, unfinished, or missed nursing care during labor and birth. J Perinat Neonatal Nurs. 2017;31(1):32-40. DOI: https://doi.org/10.1097/JPN.0000000000000203.

2. Herdman TH, Kamitsuru S. Diagnósticos de enfermagem da NANDA: definições e classificação 2018-2020. Porto Alegre: Artmed; 2018.

3. Marcomini EK, Paula NVK, Raimondi DC. Nursing Care Systematization: Applicability to Primary Care. Acta Sci Health Sci. 2020;42:e48465. DOI: https://doi.org/10.4025/actascihealthsci.v42i1.48465.

4. Lopes MVO, Silva VM. Métodos avançados de validação de diagnósticos de enfermagem (Ciclo 4). In: Herdman TH, editor. Programa de Atualização em Diagnóstico de Enfermagem. Porto Alegre: Artmed Panamericana; 2016. p. 9-51.

5. Caldeira S, Timmins F, Carvalho EC, Vieira M. Clinical validation of the nursing diagnosis spiritual distress in cancer patients undergoing chemotherapy. Int J Nurs Knowl. 2017;28(1):44-52. DOI: http://dx.doi.org/10.1111/2047-3095.12105.

6. Lucio KDB, Andriola IC, Tinôco JDS, Fernandes MIDCD, Macedo BM, Cossi MS, et al. Delay in growth in adolescents: Clinical validation of a proposed nursing diagnosis. J Pediatr Nurs. 2019;46(1):72-6. DOI: http://dx.doi.org/10.1016/j.pedn.2019.03.009.

7. Trevisan R, Weiszflog W. Michaelis Dicionário Brasileiro da Língua Portuguesa. São Paulo: Melhoramentos; 2015.

8. Apolônio FR. Validação de conteúdo do diagnóstico de enfermagem Sentimento de impotência em mulheres durante o parto normal [Dissertação]. Recife: Universidade Federal de Pernambuco; 2020.

9. Benner P, Tanner C, Chesla C. Expertise in nursing practice: caring, clinical judgment, and ethics. New York: Springer Publishing Company; 2009.

10. Breman RB, Neerland C. Nursing Support During Latent Phase Labor: A Scoping Review. MCN Am J Matern Child Nurs. 2020;45(4): 197-207. DOI: http://dx.doi.org/10.1097/NMC.0000000000000626.

11. Tiruneh FN, Chuang KY, Chuang YC. Women's autonomy and maternal healthcare service utilization in Ethiopia. BMC Health Serv Res 2017;718. DOI: http://dx.doi.org/10.1186/s12913-017-2670-9.

12. Curtin M, Savage E, Leahy-Warren P. Humanisation in pregnancy and childbirth: A concept analysis. J Clin Nurs. 2020;29(10):1744-57. DOI: http://dx.doi.org/10.1111/jocn.15152.

13. Brasil. Ministério da Saúde. Recomendação n. 024, de 16 de maio de 2019. Interrompa qualquer processo de exclusão da expressão "violência obstétrica" tendo em vista o seu reconhecimento nacional e internacional e a sua utilização pela Organização Mundial da Saúde (OMS), pelo governo de vários países e pela sociedade brasileira [Internet]. Brasília; 2019 [cited 21 Apr 21]. Available from: https://conselho.saude.gov.br/recomendacoes/2019/Reco024.pdf.

14. Gomes SC, Teodoro LPP, Pinto AGA, Oliveira DR, Quirino GS, Pinheiro AKB. Rebirth of childbirth: reflections on medicalization of the Brazilian obstetric care Rev Bras Enferm [Internet]. 2018;71(5):2594-8. DOI: http://dx.doi.org/10.1590/0034-7167-2017-0564.

15. Madhavanprabhakaran GK, D'Souza MS, Nairy K. Effectiveness of childbirth education on nulliparous women's knowledge of childbirth preparation, pregnancy anxiety and pregnancy outcomes. Nurs Midwifery Stud. 2017:e32526. DOI: http://dx.doi.org/10.17795/ nmsjournal32526.

16. Khatiwada J, Muzembo BA, Wada K, Ikeda S. Dimensions of women's empowerment on access to skilled delivery services in Nepal. BMC Pregnancy Childbirth. 2020;622. DOI: http://dx.doi.org/10.1186/s12884-020-03309-9.

17. Abd El Aliem RS, Emam AM, Sarhan AEA. Effect of Implementing Birth Plan on Women Childbirth Outcomes and Empowerment. Am J Nurs. 2020;9(3):155-65. DOI: http://dx.doi.org/10.11648/j.ajns.20200903.25.

18. Chalise GD, Shrestha S, Adhikari B. Quality of Labor and Delivery Services: Maternal Satisfaction Study from a Tertiary Hospital. Med J Shree Birendra Hosp. 2021;20(1):50-8. DOI: http://dx.doi.org/10.3126/mjsbh.v20i1.29226.

19. Prates LA, Simões TM, Wilhelm LA, Luiza C, Oliveira GSMD. Natural nascer em casa: rituais de cuidado para o parto domiciliar. Rev Bras Enferm. 2018;7(3):1247-56. DOI: http://dx.doi.org/10.1590/0034-7167-2017-0541.

20. Mei JY, Afshar Y, Gregory KD, Kilpatrick SJ, Esakoff TF. Birth Plans: What Matters for Birth Experience Satisfaction. Birth. 2016;43(2): 144-50. DOI: http://dx.doi.org/10.1111/birt.12226.

21. Silva MMJ, Nogueira DA, Clapis MJ, Leite EPRC. Anxiety in pregnancy: prevalence and associated factors. Rev Esc Enferm USP. 2017;51:e03253. DOI: http://dx.doi.org/10.1590/S1980-220X2016048003253. 
22. Stjernholm YV, Charvalho PS, Bergdahl O, Vladic T, Petersson M. Continuous Support Promotes Obstetric Labor Progress and Vaginal Delivery in Primiparous Women - A Randomized Controlled Study. Front Psychol. 2021;12:582823. DOI: http://dx.doi.org/10.3389/ fpsyg.2021.582823.

23. Reis TLR, Padoin SMM, Toebe TFP, Paula CC, Quadros JS. Autonomia feminina no processo de parto e nascimento: revisão integrativa da literatura. Rev Gaúcha Enferm. 2017;38(1):e64677. DOI: http://dx.doi.org/10.1590/1983-1447.2017.01.64677. 